\title{
RESEARCHARTICLE
}

\section{Indirect Calorimetry for Energy Requirement Measurements in Children with Hepatic Glycogen Storage Disease Type I}

\author{
Edyta Szymańska*, Ewa Ehmke vel Emczyńska, Dariusz Rokicki, Anna Tylki- \\ Szymańska, and Janusz Książyk
}

Department of Pediatrics, Nutrition and Metabolic Disorders, the Children's Memorial Health Institute, Warsaw, Poland

\begin{abstract}
Background: Patients with glycogen storage disease (GSD) type I have predisposition to exceed the ideal body mass due to high calorie diet with uncooked cornstarch (UC). Therefore, objective energy requirement measurements in these patients are crucial. The aim of this study was to measure resting energy expenditure (REE) in children with GSD type I using indirect calorimetry (IC).
\end{abstract}

Materials and methods: Nine patients with GSD type I (la:Ib; 5:4), aged 9.2 (5.5-15.8) years were included into the study. The average fasting time preceding IC was $2.7 \mathrm{~h}(\mathrm{SD} \pm 0,9)$. REE was measured using an indirect calorimeter in canopy mode. The results were compared with predicted values using Schofield's (Scho) equation and calculated from weight and height.

Results: Median body mass [median (interquartile range)] was $36.3 \mathrm{~kg}$ (19.7-60.5) and median height was $141 \mathrm{~cm}$ (105-157). Median uncooked cornstarch intake (g/24h) was 180.0 (55.0-335.0), which was $872.3 \mathrm{kcal} / 24 \mathrm{~h}(\mathrm{SD} \pm 425.6$ ) and median diet energy ( $\mathrm{kcal} / 24 \mathrm{~h}$ ) was $1443(\mathrm{SD} \pm 356)$, median total calories intake was $2189.6 \mathrm{kcal} / 24 \mathrm{~h}(\mathrm{SD} \pm 423)$. Average measured REE was 1677.6 (SD \pm 336.6 ), median predicted REE was 1272.0 (SD \pm 206.8) and median REE (Scho) was 1178.8 (SD \pm 238.2 ). Measured REE was increased in GSD I when compared to the predicted values calculated from weight and height $(p=0.001)$ and from Scho equation ( $p=0.00004)$.

Conclusion: An increased energy requirements and overweight found in children with GSD I might be due to a high calorie diet/excessive cornstarch intake which should be taken into account for their dietary management.

Received: June 22, 2018

Accepted: August 07, 2018

Published: August 27, 2018

Copyright: @ 2018 Szymańska E. This is an open access article distributed under the terms of the Creative Commons Attribution License, which permits unrestricted use, distribution, and reproduction in any medium, provided the original author and source are credited.

\section{Corresponding author:}

Edyta Szymańska, Department of Pediatrics, Nutrition and Metabolic Diseases, Children's Memorial Health Institute, Warsaw, Poland.

Email: edyta.szymanska@onet.com.pl

\section{Keywords}

Calorimetry, resting energy expenditure, glycogen storage disease

\section{Introduction}

Glycogen storage diseases (GSDs) comprise of 8 liver types: la and b, III, IV, VI, IX, XI and in 0 . Each type is a distinct entity with different medical and dietary management, but all of them have hypoglycemia as an underlying symptom in common, and all require frequent meals. Dietary restrictions of non-utilizable sugars with addition of uncooked cornstarch (CS) in type I, and high-protein diet in ketotic types (III, VI, IX) are the mainstay of treatment to manage patients for metabolic control. ${ }^{1}$

Objective methods for energy requirements assessment, such as indirect calorimetry (IC), have not been commonly used in patients with GSD. Nutritional management is therefore based on patient's age and body mass, glucose levels and results of laboratory studies 
(metabolic control). However, data on the effect of diets for various inborn errors of metabolism (IEM) on longer term nutritional status and body composition demonstrate their adverse effects. ${ }^{2}$

According to the guidelines on GSD I, nutritional management is based on a diet composed of $60-70 \%$ calories from carbohydrates, $10-15 \%$ calories from protein (to provide the daily recommended intake), and the remaining calories from fat $(<30 \%$ for children older than 2 years). ${ }^{3}$ Cornstarch dose is based on patient's body mass an height according to patient's metabolic control - either having or not hypoglycemia. ${ }^{4}$

Diet and patient's response to the therapy are described in terms of metabolic stability rather than long term nutritional and health outcomes. Since objective methods to assess actual energy expenditure are not commonly used in IEM, the aim of this study was to measure resting energy expenditure (REE) in children with GSD type I using indirect calorimetry (IC) in order to provide most "tailored" nutritional management avoiding both over - and undertreatment.

\section{Patients and Methods}

Nine patients with GSD type I (la:lb; 5:4), aged 9.2 (5.5-15.8) years were included into the study. All patients present with good metabolic control at the time of the study (table 1)

Table 1. Detailed characteristics of GSDI patients included into the study $(n=9)$

\begin{tabular}{|c|c|}
\hline Parameter & Characteristic \\
\hline $\begin{array}{l}\text { All patients: } \\
\text { - } \text { GSD la } \\
\text { - } \text { GSD lb }\end{array}$ & $\begin{array}{l}9 \\
5 \\
4\end{array}$ \\
\hline $\begin{array}{l}\text { Gender: } \\
\quad \text { - } \text { males } \\
\text { - } \text { females }\end{array}$ & $\begin{array}{l}5(55.6 \%) \\
4(44.4 \%)\end{array}$ \\
\hline Age (years) & $9.2(5.5-15.8)$ \\
\hline $\begin{array}{l}\text { Total daily energy intake (kcal)/ median } \\
\text { [interquartile range] } \\
\quad-\quad \text { GSD la } \\
\text { - GSD lb }\end{array}$ & $\begin{array}{l}1892.0(1366-2035) \\
1567.0(1211-1594)\end{array}$ \\
\hline $\begin{array}{l}\text { Body mass }(\mathrm{kg}) / \text { median [interquartile range] } \\
- \text { GSD la } \\
-\quad \text { GSD lb }\end{array}$ & $\begin{array}{l}55.0(21.3-60.5) \\
23.2(19.7-49.8)\end{array}$ \\
\hline $\begin{array}{l}\text { Height }(\mathrm{cm}) / \text { median [interquartile range] } \\
-\quad \text { GSD la } \\
-\quad \text { GSD lb }\end{array}$ & $\begin{array}{l}145.0(107.0-157.0) \\
118.0(105.0-141.0)\end{array}$ \\
\hline $\begin{array}{l}\text { BMI }\left(\mathrm{kg} / \mathrm{m}^{2}\right) / \text { median [interquartile range] } \\
-\quad \text { GSD la } \\
\text { - } \text { GSD lb }\end{array}$ & $\begin{array}{l}24.5(17.3-27.5) \\
17.9(16.7-25.0)\end{array}$ \\
\hline
\end{tabular}

The average fasting time preceding IC was $2.7 \mathrm{~h}(\mathrm{SD} \pm 0,9)$. REE was measured using an indirect calorimeter in canopy mode. Indirect calorimetry type Quark RMR Mikropolis was used, and then the data was entered into compute by the registered metabolic dietician.

The results were compared with predicted values using Schofield's (Scho) equation and calculated from weight and height.

Statistical methods: Wilcoxon test was used for statistical analysis.

\section{Results}

Median body mass [median (interquartile range)] was $36.3 \mathrm{~kg}$ (19.7-60.5) and median height was $141 \mathrm{~cm}$ (105-157). Median uncooked cornstarch intake (g/24h) was 180.0 (55.0-335.0), which was $872.3 \mathrm{kcal} / 24 \mathrm{~h}(\mathrm{SD} \pm 425.6)$ and median diet energy (kcal/24h) was 1443 (SD \pm 356$)$, median total calories intake was $2189.6 \mathrm{kcal} / 24 \mathrm{~h}(\mathrm{SD} \pm 423)$. Average measured REE was 1677.6 (SD \pm 336.6 ), median predicted REE was 1272.0 (SD \pm 206.8 ) and median REE (Scho) was 1178.8 (SD \pm 238.2 ). Measured REE was increased in GSD I when compared to the predicted values calculated from weight and height $(p=0.001)$ and from Scho equation $(p=0.00004)$ Median and interquartile range of CS intake, REE and whole caloric intake (food, CS and glucose intake) per 24 hours in patients with GSDI (Table 2A\& 2B). 
Table 2A. Median and interquartile range of CS intake, REE and whole caloric intake (food, CS and glucose intake) per 24 hours in patients with GSDI

\begin{tabular}{|l|l|}
\hline Parameter & Characteristic \\
\hline CS intake (g) & $154.0(55.0-331.0)$ \\
$-\quad$ GSD la & $180.0(95.0-320.0)$ \\
\hline GSD lb & $1892.0(1366.0-2035.0)$ \\
REE (kcal) GSD la & $1567.0(1211.0-1594.0)$ \\
\hline GSD lb & \\
\hline Caloric intake/24 h (kcal) & $2074.0(1568.0-2602.0)$ \\
- GSD la & $2190.0(2087.0-2502.0)$ \\
\hline
\end{tabular}

CS-cornstarch

$R E E$ - resting energy expenditure

Kcal-calories

Table 2B. Results from BIA $(n=22)$

\begin{tabular}{|c|c|}
\hline Parameter & Characteristic \\
\hline $\begin{array}{l}\text { Body fat }(\%) / \text { median [interquartile range] } \\
- \text { GSD I } \\
\text { - } \text { GSD III/VI/IX/O }\end{array}$ & $\begin{array}{l}38.95(28.70-50.50) \\
34.50(28.30-45.00)\end{array}$ \\
\hline $\begin{array}{l}\text { Body fat }(\mathrm{kg}) / \text { median [interquartile range] } \\
-\quad \text { GSD I } \\
-\quad \text { GSD III/VI/IX/0 }\end{array}$ & $\begin{array}{l}17.65(8.80-25.10) \\
8.25(4.50-12.70)\end{array}$ \\
\hline $\begin{array}{l}\text { Lean body mass }(\mathrm{kg}) / \text { median [interquartile range] } \\
- \text { GSD I } \\
\text { - } \text { GSD III/VI/IX/O }\end{array}$ & $\begin{array}{l}15.05(3.33-35.90) \\
14.60(2.60-29.60)\end{array}$ \\
\hline $\begin{array}{l}\text { Dry lean body mass }(\mathrm{kg}) / \text { median [interquartile } \\
\text { range] } \\
\begin{array}{l}\text { - } \text { GSD I } \\
\text { - } \text { GSD III/ } \mathrm{VI} / \mathrm{IX} / 0\end{array}\end{array}$ & $\begin{array}{l}6.75(2.50-9.00) \\
3.35(2.10-7.30)\end{array}$ \\
\hline $\begin{array}{l}\text { Body water }(\%) / \text { median [interquartile range] } \\
- \text { GSD I } \\
- \text { GSD III/VI/IX/O }\end{array}$ & $\begin{array}{l}46.4(37.90-54.00) \\
50.55(41.10-54.70)\end{array}$ \\
\hline $\begin{array}{l}\text { Body water }(\mathrm{kg}) / \text { median [interquartile range] } \\
- \text { GSD I } \\
\text { - } \text { GSD III/VI/IX/0 }\end{array}$ & $\begin{array}{l}21.50(8.40-26.90) \\
11.25(6.90-22.30)\end{array}$ \\
\hline
\end{tabular}

\section{Discussion}

Diet is a therapy in IEM. In patients with GSD, especially individuals with type I, a high carbohydrate diet used to be applied. Therefore, they are more prone to low protein intake, which may lead to reduced stature, higher Body Mass Index (BMI) and percentage body fat with lower skeletal muscle mass. ${ }^{5,6}$ Patients' metabolic profile is determined by the diet and it can be very difficult to adjust nutritional management accordingly.

So far, objective methods to assess actual energy requirements in GSD patients are not commonly used, and only sparse data on that issue are available. There has been one short report on increased REE in GSD la, which has demonstrated that these patients were shorter than controls and their REE was increased when compared to the predicted values calculated from weight and height. No difference between observed and predicted REE in the control group was reported. ${ }^{7}$ These results are consistent with the outcomes of our study - REE assessed by calorimeter was higher in these patients than values calculated for body mass, height and age. In the paper of Brazilian group presenting clinical and laboratory profile of GSDI, obesity was the side effect of CS therapy, and appeared to be associated with growth in these patients. ${ }^{8}$ In our group, in majority of patients (5/9) whose CS intake was the highest one, their BMI was $>97$ percentile. ${ }^{9}$ This leads to the conclusion, that the more CS, then higher the risk of obesity, and therefore higher REE. In non-obese patients' energy expenditure was lower, which sounds logical. Thus, unless energy requirements are assessed in an objective way, carbohydrates intake may be excessive which leads to obesity. 
In contrary to other authors, we included in our study not only type la, but also type b - with neutropenia. Patients with both types of GSD I struggle with severe hypoglycemic episodes, and thus, in contrary to the other (ketotic) types, they need more CS which led to higher REE and obesity. Neutropenia should not influence energy requirements and CS intake unless inflammatory bowel disease or other inflammatory complications due to neutropenia are present - this may cause energy unbalance. However, we did not report any differences between the groups (la and Ib) regarding either REE or CS intake.

Glycemic index of carbohydrate, the type of sugar and the proportion of proteins, mediumchain triglyceride and essential fatty acids also play an important role in the long-term metabolic control. Therefore, the role of metabolic dietitian is essential within the team.

The greatest advantage of this paper is its uniqueness, since the data on that issue are sparse, and there are no other manuscripts on calorimetry use in GSD.

The disadvantage, on the other hand, is the small study group and luck of control group. Moreover, since patients with GSD cannot fasten, the examination was performed 3-4 hours following the meal (while according to the protocol it should be performed after night fasting for e.g. the longer the fasting period, the better). Therefore, REE in these cases must have been higher, which we are aware of. Thus, the results would be difficult to compare to the control group - that is why we did not include the controls (it would be unreliable) in the study.

Nonetheless, we consider our study valuable, because any report/study in IEM providing new insight is important, as these are rare diseases with limited guidelines for managements and possibilities for proper trial conduction.

\section{Conclusion}

An increased energy requirements and overweight found in children with GSD I might be due to a high calorie diet/excessive cornstarch intake which should be taken into account for their dietary management.

\section{Acknowledgement}

This research was enabled on the basis of a grant received from the Danone Medical Trading B.V. which encompasses Nutricia Metabolics.

\section{References}

1. Bhattacharya K. Investigation and management of the hepatic glycogen storage diseases. Trans/ Pediatr. 2015;4(3): 240-248.

2. Collins JE, Leonard JV. The dietary management of inborn errors of metabolism. Hum Nutr Appl Nutr. 1985;39(4): 255-272.

3. Kishnani PS, Austin SL, Abdenur JE, et al. American College of Medical Genetics and Genomics. Diagnosis and management of glycogen storage disease type I: a practice guideline of the American College of Medical Genetics and Genomics. Genetics Med. 2014;16: e1.

4. Rake JP, Visser G, Labrune P, et al; European Study on Glycogen Storage Disease Type I (ESGSD I). Guidelines for management of glycogen storage disease type I - European Study on Glycogen Storage Disease Type I (ESGSD I). Eur J Pediatr. 2002;161(suppl 1): S112-S119.

5. Melis D, Rossi A, Pivonello R, et al. Reduced bone mineral density in glycogen storage disease type III: evidence for a possible connection between metabolic imbalance and bone homeostasis. Bone. 2016; 23;86: 79-85.

6. Burda P, Hochuli M. Hepatic glycogen storage disorders: what have we learned in recent years? Curr Opin Clin Nutr Metab Care. 2015;18(4): 415-421.

7. Feillet $F$, Bodamer OA, Leonard JV. Increased resting energy expenditure in glycogen storage disease type la, J Inherit Metab. Dis. 1998; 21: 80-81.

8. Santos BL, Souza CF, Schuler-Faccini L, et al. Glycogen storage disease type I: clinical and laboratory profile. J Pediatr (Rio J). 2014; 90(6): 572-579.

9. Szymańska E, vel Emczyńska-Seliga EE, Rokicki D, Książyk J. Body composition measurements using bioelectrical impedance analysis (BIA) in pediatric patients with hepatic glycogen storage disease - preliminary data. Clin Nutrit ESPEN. 2017;35-37. 